\title{
Correction to: Technology as an operant resource in service (eco)systems
}

\author{
Melissa Archpru Akaka · Stephen L. Vargo²
}

Published online: 19 March 2021

(c) Springer-Verlag GmbH Germany, part of Springer Nature 2021

\section{Correction to: Inf Syst E-Bus Manage (2014) 12:367-384 https://doi.org/10.1007/s10257-013-0220-5}

In the original publication of the article, the author name "Orlikowski" is misspelled as "Orlikowsky" in many occurrences.

The correct name should be "Orlikowski"

Publisher's Note Springer Nature remains neutral with regard to jurisdictional claims in published maps and institutional affiliations.

The original article can be found online at https://doi.org/10.1007/s10257-013-0220-5.

Melissa Archpru Akaka

melissa.akaka@du.edu

1 Daniels College of Business, University of Denver, 2101 S. University Blvd., Denver, CO 80208-8921, USA

2 Shidler College of Business, University of Hawaii at Manoa, 2404 Maile Way, \#C303, Honolulu, HI 96822, USA 